\title{
Nemzeti és nemzetközi szoptatási stratégiák tanulságai
}

\section{Lessons learnt from the national and international breastfeeding strategies}

\author{
Dr. Bóné Veronika¹, W. Ungváry Renáta¹, Juhászné Dr. Kun Judit Gabriella², \\ Dr. Kutas Katalin ${ }^{3}$, Gitidiszné Gyetván Krisztina4, Dr. Gárdos László ${ }^{5}$ \\ ${ }^{1}$ Semmelweis Egyetem, EKK Mentálhigiéné Intézet, ${ }^{2}$ Szoptatásért Magyar Egyesület, \\ ${ }^{3}$ Szent Kristóf Szakrendelő, 4 Zuglói Egészségügyi Szolgálat, \\ 5 Zala Megyei Szent Rafael Kórház
}

A tanulmány röviden összefoglalja a szoptatás gyakorlatának közelmúltbeli trendjeit és a szoptatástámogatás történetének fordulópontjait. A XX. században tapasztalható csökkenést a társadalom egészségével foglalkozó szakemberek sürgetö jelzései és a WHO által kiadott iránymutatások segítségével sikerült visszafordítani. Következő lépésként egységes monitorozási rendszert hívtak életre. A World Breastfeeding Trends Initiative (WBTi) részletes szempontrendszert kínál a kormányzatoknak a beavatkozások hatékonyságának mérésére. Magyarországon 2020-ban alakult újjá a szoptatás és a családbarát ellátás támogatásának érdekében a Szoptatást Támogató Nemzeti Bizottság, amelynek célja, hogy széles körü társadalmi szemléletformálással növelje a szoptatott csecsemők számát.

The study briefly summarizes recent trends in breastfeeding practice and turning points in the history of breastfeeding support. Urgent signals from public health professionals and guidelines published by WHO have successfully reversed the decreasing process in the second half of the $21^{\text {st }}$ century. The World Breastfeeding Trends Initiative (WBTi) as a standard monitoring system provides a detailed set of criteria for governments to measure the effectiveness of interventions. To effectively support breastfeeding and family-friendly care, the Hungarian National Breastfeeding Committee was reestablished in 2020.

\section{JELEN TANULMÁNY CÉLJA ÉS MÓDSZEREI}

A szoptatás támogatása új lendületet kapott Magyarországon 2020-ban, amikor kormányzati támogatással és kezdeményezésre megújult a Szoptatást Támogató Nemzeti Bizottság (SzTNB). A szervezet feladata komplex szoptatási stratégia kidolgozása a nemzetközi tapasztalatokra építve, ám a hazai sajátosságokat - a szoptatási attitűdöt, szoptatási gyakorlatot és az egészségügyi szolgáltató rendszer specialitásait - figyelembe véve. Jelen tanulmány a sikeres nemzeti szoptatási stratégiák tapasztalatait foglalja össze azzal a nem titkolt szándékkal, hogy azok ismeretével elősegítsük a hatékony magyar stratégia megalkotását. Szerzői az SzTNB tudományos munkacsoportjának felkért szakértői.
Sikeres és/vagy bemutatandó stratégiának azt tekintettük, ahol a beavatkozás széles körü, történt hatékonyságmérés és annak eredményei legalább részben pozitívak, és állami vagy kormányzati szándék jelent meg mögötte. Az irodalomkutatás első lépéseként a WHO összes - szoptatással, csecsemőtáplálással kapcsolatos - irányelvét kigyűjtöttük, és a releváns információkat összegeztük. Ezt követte az ismert keresőoldalakon, illetve tudományos adatbázisban (Google Scholar, Science Drirect, PubMed) a következő kulcsszavakra való keresés: breastfeeding strategy, WBTi, national breastfeeding committee, breastfeeding trends. A tanulmányban terjedelmi okokból nem mutatunk be minden sikeres stratégiát, azokra térünk ki, amelyek módszertanilag megfelelően megalapozottak, illetve kulturális vagy egészségügyi rendszerbeli hasonlóság okán relevánsak a hazai olvasóknak.

\section{CSECSEMŐTÁPLÁLÁSI TRENDEK}

Az anyatej az embercsecsemő túlélésének záloga, és bár a humán tej helyettesítésére már a történelem előtti időkben is tettek kísérleteket, ez a legtöbb esetben a csecsemő megbetegedésével és halálával járt. Ezért az anyai szoptatás helyettesítésére inkább a szoptatós dajkákat alkalmazták egészen a XIX. századig. Bár a kereskedelmi csecsemőtápszer-gyártás az 1800-as évek közepén megkezdődött, a mesterséges táplálás csak a XX. században kezdett nagymértékben elterjedni, amikor a higiéniai feltételek javulása miatt a tápszeres táplálás biztonságosabbá vált [1].

Noha kevés adat áll a rendelkezésünkre, annyi azonban teljesen világos, hogy az 50-60-as években a szoptatási arányok meredeken csökkentek, és 60-as évek végére sok országban elérték mélypontjukat. Az Egyesült Államokban ekkortájt az egyhetes csecsemöknek mindössze 25\%-át szoptatták és 2-3 hónapos korra ez az arány 14\%-ra csökkent [2]. Chilében az 1960-ban mért 95\%-os szoptatási arány 8 év alatt 10\%-ra csökkent [3].

Mindeközben a fejlődő országokban az agresszív tápszermarketing hatására a mesterséges táplálás egyre elterjedtebbé vált, ami megfelelő szintű higiénia és jó minőségű ivóvíz hiányában a csecsemők tömeges megbetegedéséhez és halálához vezetett. A szakemberek már a harmincas évek végén („Tej és Gyilkos” Dr. Cicely Williams beszéde 1939ben, amelyet először a Child and Family publikált - 16(1), 1977). Felhívták a figyelmet arra, hogy az etikátlan kereskedelmi marketing katasztrofális következményekhez vezet, 
ezért korlátozni kell [4].

Az egészségügyi szakemberek sokáig azt gondolták, hogy megfelelő higiénés körülmények között a tápszeres táplálás egyenértékű a szoptatással. A 70-es évekre azonban egyre több adat gyűlt össze azzal kapcsolatban, hogy a csecsemőtáplálásnak egész életre kiható következményei vannak a jó körülmények között élő gyermekek körében is, és hogy a mesterséges táplálás jelentősen hozzájárul az elhízás járványszerű terjedéséhez [5].

Egyre több szakember szorgalmazta, hogy a kedvezőtlen tendencia visszafordítására történjenek intézkedések a szoptatás védelme, népszerűsítése és támogatása érdekében. Ebben a tevékenységben élen járt a La Leche Liga, amely már 1956-ban a szoptatás sikerességét elősegítő információkkal, gyakorlati segítségnyújtással és társas támogatással segítette a szoptatni kívánó anyákat [6]. A nagy szakmai szervezetek azonban - nagyrészt civil szervezetek nyomására - csak a 80-as évektől kezdve fogalmaznak meg globális ajánlásokat, és szólítanak fel a szoptatás védelmére, elősegítésére és támogatására. Így látott napvilágot $\mathrm{Az}$ anyatejet helyettesítő termékek marketingjének nemzetközi Kódexe [7], az Innocenti Kiáltvány [8] és A csecsemő és kisgyermektáplálás globális stratégiája [9]. Az Egészségügyi Világszervezet (WHO) az UNICEF-fel közösen 1991-ben indította útjára a Bababarát Kórház Kezdeményezést (BBKK) [10] felismerve azt, hogy a szoptatás későbbi kimenetelét jelentősen befolyásolja a szülészeti és újszülött ellátás módja.

A Kezdeményezés célja, hogy olyan környezetet teremtsen a szülészeti intézményekben, amely a szoptatást normaként támogatja. A cél elérésére 10 lépést fogalmaztak meg, amelyek megvalósítása hozzájárul a szoptatás sikeres megalapozásához. Az elmúlt 30 év kutatásainak eredményei egyértelműen bizonyítják, hogy ha a szülészeti intézményben megfelelően támogatják a szoptatni kívánó anyákat, az mind a kizárólagos, mind a részleges szoptatás idejét jelentősen növeli.

\section{A „WORLD BREASTFEEDING TRENDS INITIATIVE”}

A szoptatástámogatással foglalkozó szakemberek számára kulcskérdés, milyen eszközökkel, módszerekkel növelhető a szoptató nők aránya, a szoptatás időtartama, melyek a bizonyítottan hatékony stratégiák. Erre a kérdésre nagyon sokféle válasz született már szociológiai, pszichológiai, antropológiai és evolúció biológiai megközelítésből. A szoptatást támogató nemzetközi kezdeményezés (World Breastfeeding Trends WBTi) [11] a számos befolyásoló tényező közül azokat vizsgálja, amelyek a mindenkori kormányzat hatáskörébe tartoznak. A csecsemő- és kisgyermektáplálás globális stratégiája célkitúzéseinek monitorozására a WBTi szempontrendszert dolgozott ki 15 különböző indikátorral (melyek közül 10 a kormányzati szoptatástámogatási intézkedések megvalósítási fokának értékelésére, öt pedig a gyakorlati eredmény felmérésére szolgál [31]), az egyes indikátorok értelmezését, tartalmát bemutató módszertannal, program- mal, és az eredmények feldolgozását, összehasonlítását lehetővé tevő globális, minden érdeklődő számára nyitott adatbankkal. Az indikátorok pontozása révén világosan kirajzolódnak a hiányosságok, azok az elemek, ahol változtatásra, fejlesztésre van szükség. A kezdeményezéshez, amely először nyolc dél-ázsiai ország szoptatástámogatási helyzetképének összeállításával, és a kritériumrendszer tesztelésével kezdődött, immár 98 ország csatlakozott - Magyarország ezidáig (2021 tavasza) nem szolgáltatott adatokat. A cél az volna, hogy minden ország 3-5 évenként újraértékelje a kormányzati szoptatástámogatás színvonalát az indikátorrendszer segítségével. Így hosszú távú stratégia kidolgozására nyílik lehetőség a globális adatbank adataira alapozva: a statisztikai adatelemzésböl kiderül, melyek azok a lépések, amelyekkel hatékonyan befolyásolható a szoptatási arány és időtartam. Különösen izgalmasak lehetnek az egyes országok és térségek közötti összehasonlítások, amelyek rávilágítanak, hogy nem mindenütt ugyanazok a lépések bizonyulnak a leghatásosabbnak, illetve a hiányosságok is jellemzően különböző területeken jelentkeznek.

Gupta és munkatársai 2018-ban foglalták össze [11], hogy milyen tanulságok adódtak a WBTi első tíz évének eredményeiből. Globális jelenség a szoptatáspolitika hiánya vagy gyengesége, amely elsősorban az alulfinanszírozottsággal és bizonyos indikátorok esetében a szankciók hiányával függ össze. 2005 és 2016 között 35 olyan ország volt, amely több ízben is készített beszámolót az indikátorrendszer segítségével, náluk a trendek is követhetők. Az adatok 29 ország esetében egyértelműen jelentős javulást mutatnak az összpontszám tekintetében, legalábbis ami a szoptatáspolitikai intézkedések területét illeti. Ugyanakkor a kérdés összetettségét jelzi, hogy ez a pozitív tendencia nem eredményezte a szoptatás időtartamának növekedését, kivéve az első életórában megkezdett szoptatás indikátorát, amely szoros összefüggést mutatott a bababarát kórházak arányával. A hat hónapos kizárólagos szoptatási arány átlaga nem változott a vizsgált időszakban számottevően, 40 százalék körüli maradt, a cumisüveges táplálás aránya azonban nőtt. Egyes országokban, például DélKoreában a javuló szoptatáspolitika ellenére is csökkent a kizárólagos szoptatási arány. Sri-Lankán és Brazíliában azonban a kérdéses időszakban szignifikánsan nőtt a szoptatás aránya a gyakorlati indikátorok tanúsága szerint. Nem mellékes a finanszírozás kérdése sem. Egy világbanki elemzés és prognózis szerint [12] a szoptatás promóciójára fordított pénz megtérülhet a szoptatási arányok növekedésének köszönhetően.

Elgondolkodtató Haroon és munkatársainak elemzése, [13] amelyből kiderül, hogy az egyes intervenciók szoptatásra gyakorolt hatása a fejlődő országokban nagyobb, mint a fejlett országokban. A szoptatással kapcsolatos edukáció és a gyakorlati támogatás növelte a kizárólagos szoptatás arányait. Az egyéni és a csoportos felkészítés, valamint a szoptatástámogatás kombinációja bizonyult leghatékonyabbnak a kizárólagos szoptatási arányok növelésében. 


\section{SIKERES NEMZETI SZOPTATÁSI STRATÉGIÁK}

A szoptatás nagyon sok tényezőn múlik, ugyanakkor a szoptatási viselkedés érzékeny a változásokra, így, ha megfelelő intézkedések születnek, nagyon gyors és mérhető emelkedés tapasztalható a mérőszámokban [14]. A szoptatási arányok növekedésére a leghatékonyabb programok mindig komplexek, hatékonyságuk kontextusfüggő, és akkor működnek jól, ha a rendszerszemlélet elveit követve figyelembe veszik a szoptató anya körül rendeződő egyéb hálózatokra gyakorolt hatást [15]. Több tanulmány számol be sikertelen vagy félsikerrel végig vitt beavatkozásokról. NagyBritanniában a hat hónapos kizárólagos szoptatási arány rendkívül alacsony volt (1\% 2010-ben), az összefoglaló tanulmányok az elemzett kutatások kudarcának okát a rendszerszemlélet hiányában látják. Többnyire olyan beavatkozások történtek, amelyek kizárólag az anyát célozták, és nem vették figyelembe az anya körüli társas kapcsolatok hatását az anyai attitűdre [16]. Ugyanakkor a WBTi 2016-os beszámolója szerint a 6 hónapos kizárólagos szoptatási arány már 17\%, ami azt jelzi, hogy a hosszú távú hatás kimutatható [32]. Több jó példát is látunk azonban világszerte a komplex beavatkozások tervezésére, végrehajtására és eredményességére. Kenyában nemzeti irányelvet dolgoztak ki, amely leginkább a „Tíz lépés” tizedik lépésére épül és a Bababarát Közösségi Kezdeményezés (Baby Friendly Community Initiative - BFHI) nyolc pontos tervére: azaz központilag finanszírozott rendszer jött létre az önkéntes segítők és egészségügyi személyzet képzésére és támogatására. A helyi közösségek folyamatos támogatást kapnak, monitorozzák őket, mentorálásban, szupervízióban részesülnek. A beavatkozás hatására 1998 és 2014 között 15\%-ról 61\%-ra nőtt a kizárólag szoptatottak aránya [17].

Ázsiában kiemelkedő eredményeket ért el Vietnám, amely összetett nemzeti stratégiát - az Alive \& Thrive programot - hozott létre. 2010 és 2014 között a program indulásakor résztvevő régiókban az öt hónapos kori kizárólagos szoptatási arány 18,9\%-ról 57,8\%-ra emelkedett. Az országban 2014 óta minden szülészeti intézmény számára kötelező a Tíz lépés betartása [18].

Latin-Amerika országai közül Brazíliában történt komoly elörelépés évtizedek alatt a különböző beavatkozások hatására. 1975-ben a szoptatás átlagos időtartama 2,5 hónap volt, 2008-ra ez 11,3 hónapra, a 6 hónapos kori kizárólagos szoptatás pedig 41\%-ra nőtt, 14-szeres növekedést mutatva [19]. A brazil intézkedések többek között a Kódex betartására, a szülési szabadság meghosszabbítására, az anyatejbankok támogatására és a BBKK elindítására irányultak. Brazíliában is különös figyelmet fordítottak a "Tíz lépés” utolsó lépésére, azt tapasztalták ugyanis, hogy az intézkedések erősebben hatnak a hosszú távú szoptatásra, illetve a hosszan tartó kizárólagos szoptatásra, ha a közösségi támogatás is jelentős [20].

Ugyanebben a régióban, Bolíviában a WBTi 2008-as első felméréséhez képest szoptatáspolitikai intézkedések- ben 2017-re jelentős, 27 százalékos előrelépés történt, amit nem kísért a szoptatási mutatók egyöntetű növekedése, bár a 6 hónapos korig kizárólagos szoptatás aránya 54-ről 58 százalékra nőtt, a szoptatási időtartam medián értéke viszont 20-ról 15 hónapra csökkent, miközben a cumisüveghasználók aránya is jelentősen nőtt. Több országban is megfigyelhető hasonló tendencia, ami azt mutatja, hogy a globalizáció hatását és a szoptatási kultúra hanyatlását még a komoly szoptatási hagyományokkal rendelkező országokban is nehéz ellensúlyozni [21]. Ugyanakkor Whitford és munkatársai már 2018-ban felvetették [22], hogy az ellentmondásosnak tűnő adatok hátterében az adatgyűjtési módszerek és időpontok különbségei, a nem egységes definíciók alkalmazása áll. Van, ahol a rutin egészségügyi ellátás időpontjaiban gyűjtenek adatot, Dél-Kelet Ázsiában nemzeti felmérések során rendszeresen gyűjtött adatok állnak rendelkezésre, míg Oroszországban és Kínában semmilyen szisztematikus formában nincs az ország egészére kiterjedő adatgyújtés. Ahhoz, hogy valóban megbízható következtetéseket vonhassunk le, és ezek a szoptatáspolitika hatékonyságának elbírálására is alkalmasak lehessenek, világszerte egységes kritériumok alapján és egységes időpontokban kell az adatgyűjtésnek történnie. A Whitford és munkatársai által felvetett probléma Magyarországon is jelen van: a védőnői adatgyűjtés szerint 2018-ben a hat hónapos kori kizárólagos szoptatás aránya 34 százalék volt, míg a Kohorsz '18 kutatásban csupán 17 százalék [23,24,33]. Attól függően, hogy például egy készülő WBTi jelentésbe melyik kerül bele, egészen más lehet a szoptatási helyzetkép megítélése.

Európában is több jó példával találkozunk. Svédország korán adoptálta az Innocenti kiáltvány ajánlásait, rendelkezik 50 hét fizetett szülési szabadsággal és ennek idejére munkahelyvédelmi intézkedésekkel. 1973 óta működik önkéntes alapokon a Szoptató anyák támogató csoportja. 1983-ban elfogadták a Kódexet, és 2013-ban tovább szigorították a tápszerek marketingjét. A Bababarát Kezdeményezés csatlakozást követően 1993 és 1997 között mindegyik szülészet elnyerte a címet. Eközben a hat hónapos kori kizárólagos szoptatás aránya 50\%-ról $73 \%$-a nőtt $[25,26]$. A szoptatás támogatásáért tett, sokszor kevés eredménnyel járó erőfeszítések hatására bizonyos mértékű kifáradás is jellemzi a törekvéseket [14].

Horvátország jó példa arra, hogy egy sikeresen induló, ám egy ponton megtorpanó kezdeményezés újra lendületet kaphat. 1993-ban bevezették a bababarát kórházak rendszerét, 1998-ra 34-ből 15 szülészet vált azzá. Ugyanakkor a folyamatos kódexsértések, illetve a kórházi ajándékcsomag megjelenésével az eredmények visszaestek. 2007-ben a kormányzat felismerte a változtatás szükségességét, a szoptatást támogató nemzeti bizottság nyomására betiltották a kórházi csomagokat, UNICEF tájékoztató anyagokat fordítottak le és terjesztettek, és 2015-re a szülészetek 94\%-a érte el a bababarát minősítést. Ennek hatására újra emelkedni kezdtek a szoptatási mutatók [27]. 
Olaszországban nagy hagyománya van a szoptatásnak: 2000-ben 81,1 \%-át szoptatták a csecsemőknek, 2013-ban már 85,5\%-át, az átlagos szoptatási időszak is emelkedett eközben 6,2 hónapról 8,3-ra. Kultúrájukban nagy tisztelet övezi a kismamákat, a szoptatás a csecsemőtáplálási norma, és mindezt rendszeres hirdetési kampányokkal erősítik is. 1990-ben innen indult az Innocenti kezdeményezés, az összes WHO-ajánlást betartják, és 2015-ben a Gyermekgyógyászok Társasága deklarálta is a szoptatást normaként, és számos ajánlást tett a szoptatás támogatására. A Bababarát Közösségi Kezdeményezés részeként létrehozott szoptatásbarát gyermekorvosi praxisokban elérhető képzett szoptatássegítő, akár napi viziteket biztosítanak szoptatási probléma esetén, és hetente szerveznek szoptatástámogató anyacsoportokat - ezekben a praxisokban a csecsemők 62\%-a volt kizárólag szoptatott 5 hónapos korig szemben a terület 30\%-os arányával [28]. A szoptatásban nehezítő tényezőként jelenik meg a munkába való korai visszatérés szándéka és az a nyomás-, illetve szégyenérzet, hogy aki nem szoptat, az nem gondoskodik megfelelően a gyermekéről [29].

A legösszetettebb kormányzati szándékot, forrásokat, egységes szakmai támogatással bíró nemzeti stratégiát jelenleg Ausztráliában lehet megfigyelni. A 2019-ben útjára indított program céljai között 2022-re a hat hónapos korig tartó kizárólagos szoptatás arányának 40\%-ra, majd 2025-re 50\%-ra növelése szerepel, továbbá a legalább 12 hónapos korig tartó teljes szoptatási időtartam. A stratégia folyamatos, nincs tervezett végpontja, ugyanakkor 2 évente felülvizsgálják, illetve öt évente értékelik az eredményeit. A megvalósítás lépései között van a szülők evidencia alapú tájékoztatása, a bababarát területek számának növelése, a tápszermarketinget korlátozó törvénykezés megerősítése, a megfelelő szoptatástámogató tudással rendelkező egészségügyi dolgozók számának növelése és a társadalom figyelmének felhívása a szoptatás jelentőségére [30].

\section{A MAGYAR SZOPTATÁSTÁMOGATÁS MÚLTJA ÉS MEGLÉVŐ ALAPJAI}

A magyar szoptatástámogatási rendszer alapja a védőnői rendszer, mely nem véletlenül lett hungarikumnak nyilvánítva. A védőnő a várandósság megállapításától végigköveti az új baba-mama diád útját: prenatálisan minimum 4 személyes találkozás során a terhességről, szülésről, csecsemőgondozásról, szoptatásról egyénre szabott információk átadása mellett a bizalmi kapcsolat kiépítése, személyre szabott gondozás is történik. A szülészeti intézmény értesíti a hazaadásról a védőnőt, aki 48 órán belül meglátogatja a családot otthonában. Mivel a tejbelövellés zömmel ebben az időszakban történik, gyakran az apák is jelen vannak ekkor, ez a látogatás kulcsfontosságú lehet. Az ekkor adott érzelmi és információs támogatás segít a normatív krízisállapottal történő eredményes megküzdésben, a szülői kompetenciaérzet kialakulásában, amik a sikeres szoptatáshoz szükségesek. Az első hónapban hetente, majd az első félévben havonta történő találkozások alkalmával is proaktív, személyre szabott szoptatási tanácsadás történhet. Sajnálatos módon a védőnők törzsképzése kevés tudást ad át a szoptatás know how-járól. A team másik fontos szereplője a gyermekorvos, akiknek a képzése még kevesebb információt biztosít ebben a témakörben, ugyanakkor az indikátorrendszerben megjelenik az anyatejes táplálás, mely motiváló erővel bír. 2018-ban a koraszülöttek, 2019-ben az egészséges csecsemők táplálásáról készült korszerū, szoptatástámogató irányelv, melynek oktatása, terjesztése még teendőket kíván. Az alapellátás körében meg nem oldható szoptatási problémákra az országban számos szoptatási ambulancián tudnak közfinanszírozottan megoldást találni. Továbbá számos szoptatástámogató anyacsoport működik önkéntes, vagy csak jelképes támogatást igénylő alapon az országban. Magánellátás keretében szoptatási tanácsadóval történő konzultációra is lehetőség van.

\section{A MAGYAR SZOPTATÁST TÁMOGATÓ NEMZETI BIZOTTSÁG}

Magyarországon az egészségügyi miniszter tanácsadó testülete a Szoptatást Támogató Nemzeti Bizottság. Legfőbb feladata, hogy egy szoptatásbarát társadalom, családközpontú és bababarát szülészeti és újszülött ellátás valósuljon meg az egész országban és a születési helytől függetlenül biztosítsa az esélyegyenlőséget minden újszülött és édesanya számára. A bizottságban mintegy 60 szakértőnek - egészségügyi és nem egészségügyi szakterületek képviselőjének - legfőbb célja és törekvése, hogy hatékony módszertannal, képzéssel, tájékoztatással szemléletváltást érjen el az egész társadalomban, és ezáltal rövid és hosszú távon is és megnövelje a szoptatott csecsemők számát.

A cél elérése érdekében az SZTNB egyik fő feladatának tartja a családközpontú és bababarát kórházi ellátás rendszerének, akkreditációjának és hosszú távú müködésének a kialakítását. Ugyancsak alapvető fontosságúnak tartja a korszerű laktációs ismeretekkel, gyakorlati, kommunikációs és mentálhigiénés készségekkel rendelkező szülészeti és neonatológiai szakemberek kiképzését. A hosszú távú eredmények fontos feltétele, hogy a kórházból történt hazaadást követően biztonságos és szoptatást segítő bababarát alapellátó praxisok várják az édesanyákat és gyermeküket, ezért az SZTNB az egész országban mindenki számára egyformán elérhető szoptatás támogató rendszer és anyatejgyűjtő hálózat kialakítását is legfőbb céljai között tartja és dolgozza ki szakmai és képzési egyedi koncepciót a nemzetközi ajánlások és szakirodalom figyelembevételével. A bizottság célja egy támogató társadalmi környezet és családbarát egészségügyi ellátás kialakítása, amelyben valamennyi érintett szakembernek lehetősége van a magas szintű képzések révén a korszerű, naprakész ismeretek elsajátítására mind a természetes szülés, a családbarát egészségügyi ellátás és a szoptatástámogatás területén. 


\section{IRODALOMJEGYZÉK}

[1] Stevens EE., Patrick TE, Pickler R: A history of infant feeding. J Perinat Educ. 2009; 18: 32-39. https://doi.org/10.1624/105812409X426314

[2] Fomon S: Infant feeding in the 20th century: formula and beikost. The Journal of Nutrition. 2001; 131: 409S-420S. https://doi.org/10.1093/jn/131.2.409S

[3] Minchin M: Going global: perfecting formula feeding 1950s-1980s. Milk matters : infant feeding and immune disorder. Translated Milk matters: infant feeding and immune disorder.] Milk Matters Pty Ltd. 2015, pp.

[4] Jelliffe DB, Jelliffe EF: The Infant Food Industry and International Child Health International Journal of Health Services. 1977; 7: 249-254. https://doi.org/10.2190/RT3Q-PL85-T7VM-3LB3

[5] Jelliffe DB, Jelliffe EF: Fat babies: prevalence, perils and prevention. J Trop Pediatr Environ Child Health. 1975; 21: 123-159. https://doi.org/10.1093/tropej/21.3.124

[6] Wiessinger D, West D, Pitman T: A La Leche Liga. In: Réka Patik. (ed.) A szoptatás női múvészete. In: Réka Patik. (szerk.) Translated A szoptatás női múvészete.] La Leche Liga Magyarország Egyesület, Budapest. 2013, pp. 411-420 [Hungarian]

[7] WHO: International Code of Marketing of Breast-milk Substitutes. In: World Health Organization (ed). Geneva, 1981.

[8] Innocenti Declaration. Breastfeeding in the 1990s: A Global Initiative. Florence, Italy, 1990.

[9] Global strategy for infant and young child feeding. World Health Organization, Geneva, 2003.

[10] Health, World, Organization: Implementation guidance: protecting, promoting and supporting breastfeeding in facilities providing maternity and newborn services - the revised Baby-friendly Hospital Initiative. In: WHO expert panel (ed). Geneva: WHO, 2018.

[11] Gupta A, Suri S, J, P. Dadhich JP et al.: The World Breastfeeding Trends Initiative: Implementation of the Global Strategy for Infant and Young Child Feeding in 84 countries. Journal of Public Health Policy. 2019; 40: 3565. https://doi.org/10.1057/s41271-018-0153-9

[12] Shekar M, Kakietek J, Dayton Eberwein, J, Walters D: An Investment Framework for Nutrition. 2017 International Bank for Reconstruction and Development. https://doi.org/10.1596/25292

[13] Haroon S, Das JK, Salam RA, et al.: Breastfeeding promotion interventions and breastfeeding practices: a systematic review. BMC Public Health. 2013; 13: S20. https://doi.org/10.1186/1471-2458-13-S3-S20

[14] Rollins NC, Bhandari N, Hajeebhoy N et al.: Why invest, and what it will take to improve breastfeeding practices? The Lancet. 2016; 387: 491-504. https://doi.org/10.1016/S0140-6736(15)01044-2

[15] Gallegos D, Parkinson J, Duane S et al.: Understanding breastfeeding behaviours: a cross-sectional analysis of associated factors in Ireland, the United Kingdom and
Australia. Int Breastfeed J. 2020; 15: 103

https://doi.org/10.1186/s13006-020-00344-2

[16] Emmott EH, Page AE, Myers S: Typologies of postnatal support and breastfeeding at two months in the UK. Social Science \& Medicine. 2020; 246: https://doi.org/10.1016/j.socscimed.2020.112791

[17] Kavle JA, Ahoya B, Kiige L et al.: Baby-Friendly Community Initiative-From national guidelines to implementation: A multisectoral platform for improving infant and young child feeding practices and integrated health services. Matern Child Nutr. 2019; 15 Suppl 1: e12747. https://doi.org/10.1111/mcn.12747

[18] Walters D, Horton S, Siregar AY et al.: The cost of not breastfeeding in Southeast Asia. Health Policy Plan. 2016; 31: 1107-1116. https://doi.org/10.1093/heapol/czw044

[19] Pérez-Escamilla R: Breastfeeding in Brazil: major progress, but still a long way to go. Jornal de Pediatria. 2017; 93: 107-110. https://doi.org/10.1016/j.jpedp.2016.10.004

[20] Pérez-Escamilla R, Martinez JL, Segura-Pérez S: Impact of the Baby-friendly Hospital Initiative on breastfeeding and child health outcomes: a systematic review. Maternal \& Child Nutrition. 2016; 12: 402-417. https://doi.org/10.1111/mcn.12294

[21] Infant Feeding and Globalisation. WABA Position Statement, 2011.

[22] Whitford H, Hoddinott P, Amir LH et al.: Routinely collected infant feeding data: Time for global action. Maternal and Child Nutrition. 2018; 14: https://doi.org/10.1111/mcn.12616

[23] A csecsemők táplálása Available from: <https://www. kohorsz18.hu/eredmenyek/elozetes-eredmenyek/49csecsemok-taplalasa.html> [accessed: 2020].

[24] Boros J, Halász A, Kapitány B, et al.: Kutatási koncepció. Kohorsz '18 Magyar Születési Kohorszvizsgálat. Kutatási Jelentések 100, 2019.

[25] Hofvander Y: Breastfeeding and the Baby Friendly Hospitals Initiative (BFHI): organization, response and outcome in Sweden and other countries. Acta Paediatr. 2005; 94: 1012-1016. https://doi.org/10.1080/08035250510032781

[26] Lubold AM: Historical-qualitative analysis of breastfeeding trends in three OECD countries. International Breastfeeding Journal. 2019; 14: 36.

[27] Grguric J, Zakarija-Grkovic I, Pavicic Bosnjak A, et al.: A Multifaceted Approach to Revitalizing the Baby-Friendly Hospital Initiative in Croatia. J Hum Lact. 2016; 32: 568573. https://doi.org/10.1177/0890334415625872

[28] Milinco M, Cattaneo A, Macaluso A et al.: Prevalence of breastfeeding in a baby-friendly pediatric practice: an experience in Trieste, Italy. International Breastfeeding Journal. 2019; 14: 44. https://doi.org/10.1186/s13006-019-0239-4 
[29] Demaria AL, Ramos-Ortiz J, Basile K: Breastfeeding trends, influences, and perceptions among Italian women: a qualitative study. International Journal of Qualitative Studies on Health and Well-Being. 2020; 15: https://doi.org/10.1080/17482631.2020.1734275

[30] Council, Coag Health: Australian National Breastfeeding Stategy 2019 and beyond. 2019.
[31] https://www.worldbreastfeedingtrends.org/resources/ wbci-tool Megtekintve: 2021.04.30.

[32] https://www.worldbreastfeedingtrends.org/wbti-countryreport.php Megtekintve: 2021.04.30

[33] https://kohorsz18.hu/eredmenyek/elozetes-eredmenyek/49-csecsemok-taplalasa.html Megtekintve: 2021. 04.30 .

\title{
A SZERZŐK BEMUTATÁSA
}

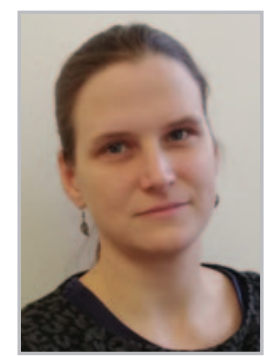

Dr. Bóné Veronika 2003-ban szerzett szociológus diplomát a Pázmány Péter Katolikus Tudományegyetemen, 2020ban szerzett doktori fokozatot. 2014 és 2021 között a Semmelweis Egyetem laktációs szaktanácsadó képzésének irányítója, 2020 óta a Szoptatást Támogató Nemzeti Bizottság tudományos munkacsoportjának vezetője.

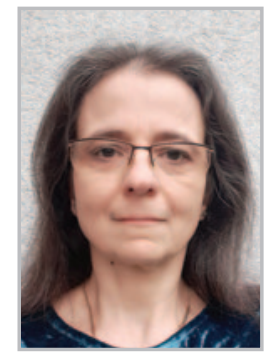

Juhászné Dr. Kun Judit orvos, IBCLC laktációs szaktanácsadó, 2004 óta vesz részt egészségügyi szakemberek szoptatás menedzsmenttel kapcsolatos továbbképzésében, a Semmelweis Egyetem laktációs szaktanácsadó szakirányú továbbképzésének oktatója, az SZTNB Bababarát Kórház Kezdeményezés Munkacsoportjának és Jogi Munkacsoportjának vezetője.

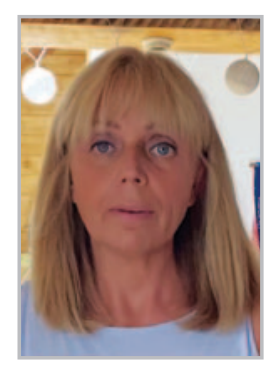

Gitidiszné Gyetván Krisztina 2000 óta dolgozik Zuglóban védőnőként, emellett végzett IBCLC laktációs szaktanácsadó és perinatális tanácsadó. 2006 óta a korábbi az akkori SZTNB tagja és titkára, 2020 óta az újjáalakult Szoptatást Támogató Nemzeti Bizottság alelnöke.

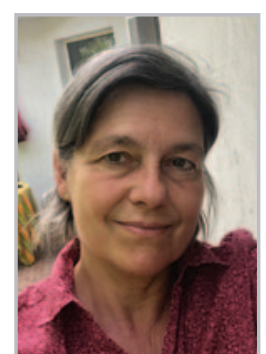

W. Ungváry Renáta 2001-től La Leche Liga szoptatási tanácsadó, 2003-tól nemzetközi vizsgával rendelkező laktációs szaktanácsadó (IBCLC) A Szoptatást Támogató Nemzeti Bizottság tagja, a Semmelweis Egyetem laktációs szaktanácsadó szakirányú továbbképzésének ügyvivő szakértője

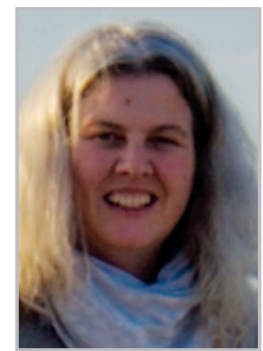

Dr. Kutas Katalin csecsemő- és gyermekgyógyász, IBCLC laktációs szaktanácsadó. 2012 óta dolgozik házi gyermekorvosként, tagja a Biztos Kezek Alapellátó Gyermekorvosok Tudományos Társaságának, a megalakult SZTNB Bababarát terület munkacsoportjának vezetője.

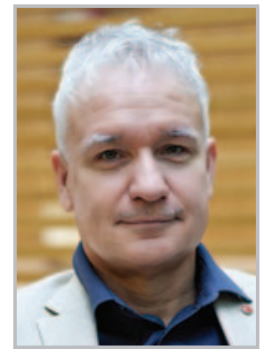

Dr. Gárdos László csecsemő és gyermekgyógyász, neonatológus és gasztroenterológus főorvos, a Zala Megyei Szent Rafael Kórház Csecsemő- és Gyerekosztályának vezetője. 2020-tól a Szoptatást Támogató Nemzeti Bizottság elnöke, valamint az Egészségügyi Szakmai Kollégium Neonatológia Tagozatának elnöke, valamint a Magyar Gyermekorvosok Társaságának elnöke. A Magyar Koraszülött és Újszülött Mentő Alapítvány kuratóriumának elnöke, a Zala megyei Koraszülöttmentő és Gyermekintenzív Alapítvány tagja.

\section{IME Vezetöi eszköztár - Kontrolling Konferencia}

\author{
2021. december 2.
}

